\title{
Perancangan Antarmuka Aplikasi Konversi Bilangan dan Warna Berbasis Android
}

\author{
Yesi Sriyeni $^{1)}$, Maria Veronica ${ }^{2)}$ \\ ${ }^{12)}$ Program Studi Sistem Informasi, STMIK PalComTech Palembang \\ Jalan Basuki Rahmat No.05 Palembang 30127 \\ Email : just.yessi@gmail.com ${ }^{1)}$, mariaveronica@palcomtech.ac.id ${ }^{2}$
}

\begin{abstract}
Learning activities do not always have to be done in the form of face-to-face lecture meetings. Learning can be done anywhere as long as it is supported by appropriate tools such as multimedia. The use of appropriate and interesting learning multimedia is felt necessary to increase student interest and learning achievement. Just like the material conversion of numbers and colors that have been considered as material that is quite difficult to be absorbed directly by students. Therefore, it is deemed necessary to design a media that can help lecturers convey material conversion of numbers and colors lighter and the material will be more easily understood by students. The multimedia interface design of learning numbers and color conversions is designed to be developed on the Android platform with a user centered design (UCD) approach. Interface testing is still carried out by researchers and only a few user samples. This is done in order to get feedback from a sample of users regarding the interface design that has been made so that it is right on target. There are several pages consisting of a splash page, a menu page, an introductory page, a study material page, a number calculator page, a color calculator page, a practice page, and a quiz page. Specifically for the quiz page, all quiz questions are planned to be timed. It aims to measure the success of absorption of numbers and color conversion material in the teaching and learning process carried out by students and lecturers.
\end{abstract}

Keywords : android, multimedia, interface, calculator

\begin{abstract}
ABSTRAK
Kegiatan pembelajaran tidaklah harus selalu dilakukan dalam bentuk pertemuan kuliah langsung bertatap muka. Belajar bisa dilakukan dimana pun asalkan didukung dengan tools yang tepat seperti multimedia. Penggunaan multimedia pembelajaran yang tepat dan menarik dirasa perlu untuk meningkatkan minat dan prestasi belajar mahasiswa. Sama halnya seperti materi konversi bilangan dan warna yang selama ini dianggap sebagai materi yang cukup susah untuk diserap langsung oleh mahasiswa. Oleh karena itu dirasa perlu merancang sebuah media yang dapat membantu dosen menyampaikan materi konversi bilangan dan warna dengan lebih ringan dan materi pun akan lebih mudah dipahami oleh mahasiswa. Desain antarmuka multimedia pembelajaran konversi bilangan dan warna ini dirancang untuk dikembangkan pada platform android dengan pendekatan user centered design (UCD). Pengujian antarmuka masih dilakukan oleh peneliti dan beberapa sampel pengguna saja. Hal ini dilakukan guna mendapatkan umpan balik dari sampel pengguna mengenai desain antarmuka yang sudah dibuat sehingga tepat sasaran. Terdapat beberapa halaman yang terdiri dari halaman awal (splash page), halaman menu, halaman pendahuluan, halaman materi belajar, halaman kalkulator bilangan, halaman kalkulator warna, halaman latihan, dan halaman kuis. Khusus untuk halaman kuis, pengerjaan semua soal kuis direncanakan untuk diberi batas waktu. Hal ini bertujuan untuk mengukur keberhasilan penyerapan materi konversi bilangan dan warna dalam proses belajar mengajar yang dilakukan oleh mahasiswa dan dosen.
\end{abstract}

Kata kunci : android, multimedia, antarmuka, kalkulator 


\section{Pendahuluan}

Sebagian mahasiswa terkadang merasa cukup kesulitan untuk memahami materi konversi bilangan. Mempelajari materi dari buku teks dan perkuliahan di kelas dirasa tak cukup jelas. Butuh usaha lebih untuk bisa meningkatkan minat belajar tentang konversi bilangan yang sebenarnya membutuhkan penalaran logika yang tajam. Disinilah peran sebuah media belajar diperlukan.untuk meningkatkan minat belajar. Kombinasi antara teks, gambar, video dan bentuk lainnya atau yang biasa disebut multimedia diharapkan bisa membantu mengubah suasana belajar yang konvensional menjadi lebih menarik. Multimedia pembelajaran dapat diartikan sebagai aplikasi multimedia yang digunakan dalam proses pembelajaran. Multimedia pembelajaran juga dapat digunakan untuk menyalurkan pesan yang dapat berupa pengetahuan, keterampilan, dan sikap. Multimedia pembelajaran juga dapat merangsang pilihan, perasaan, perhatian dan kemauan siswa sehingga secara sengaja proses belajar terjadi, bertujuan dan terkendali (Daryanto, 2010). Kehadiran multimedia pembelajaran sangat membantu dalam proses pencapaian tujuan pembelajaran sehingga hasilnya sesuai harapan (Kartikasari, 2016). Selaras dengan tujuan penggunaannya, pengembangan multimedia pembelajaran konversi bilangan dan warna dikhususkan untuk dapat digunakan oleh dosen dan mahasiswa agar mampu memahami materi konversi bilangan dan warna dengan mudah dan menarik.

Penggunaan aplikasi yang dikatakan mudah dan menarik sangat erat hubungannya dengan desain antarmuka yang baik. Desain antarmuka merupakan seperangkat alat/elemen yang digunakan untuk memanipulasi objek digital (Kartikasari, 2016., Roth, 2017). Desain antarmuka (user interface) haruslah memenuhi beberapa aspek, diantaranya attractive, pragmatic, dan hedonic (Rauschenberger, 2013). Selain itu, aspek estetik visual dan aspek fungsi juga harus diperhatikan (Wibawanto, 2017), karena nilai estetika atau keindahan menjadi hal utama yang dapat menunjang suatu hasil karya sehingga dapat dinikmati oleh panca indera (Fauzia, 2016). Adapun bagan aspek desain antarmuka dapat dilihat pada gambar 1 .

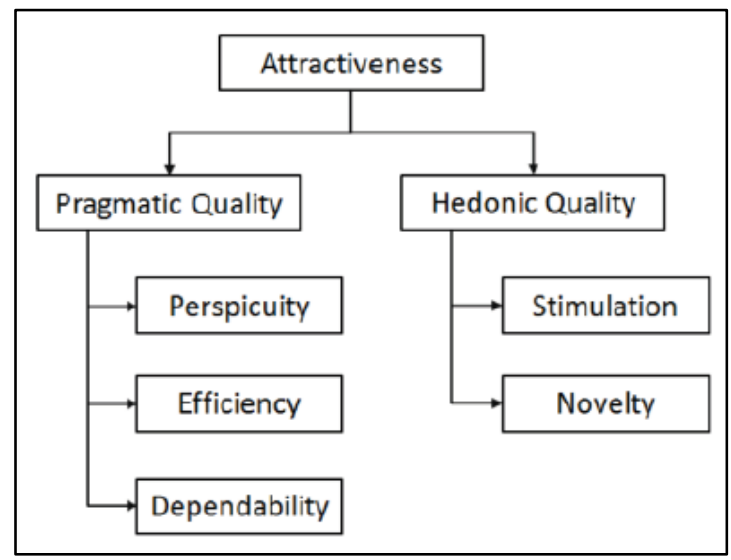

Gambar 1. Aspek Desain Antarmuka [4,5]
Implementasi pengembangan aplikasi multimedia pembelajaran dapat saja dilakukan pada personal computer (PC) atau smartphone. Beberapa aplikasi multimedia sedang ramai dikembangkan pada platform android yang diakses menggunakan smartphone. Kini, smartphone telah menjadi kebutuhan pokok bagi setiap orang karena dinilai mudah dalam hal penggunaannya (Tanzil, 2018).

Tidak hanya untuk menjadi media komunikasi, smartphone juga dapat dimanfaatkan sebagai media informasi maupun media hiburan, Peningkatan pengguna smartphone di Indonesia sejak tahun 2014 sampai tahun 2018 menunjukkan angka yang signifikan, yaitu berada pada rentang 30 sampai lebih dari 100 juta pengguna. Indonesia menjadi negara keempat terbesar pengguna smartphone setelah China, India, dan Amerika (Millward, 2014). Adapun grafiknya ditunjukkan pada gambar 2. Gambar 2 menunjukkan potensi besar untuk memutuskan bahwa pengembangan multimedia pembelajaran konversi bilangan dan warna sebaiknya dikembangkan dalam platform android yang dapat diakses menggunakan smartphone.

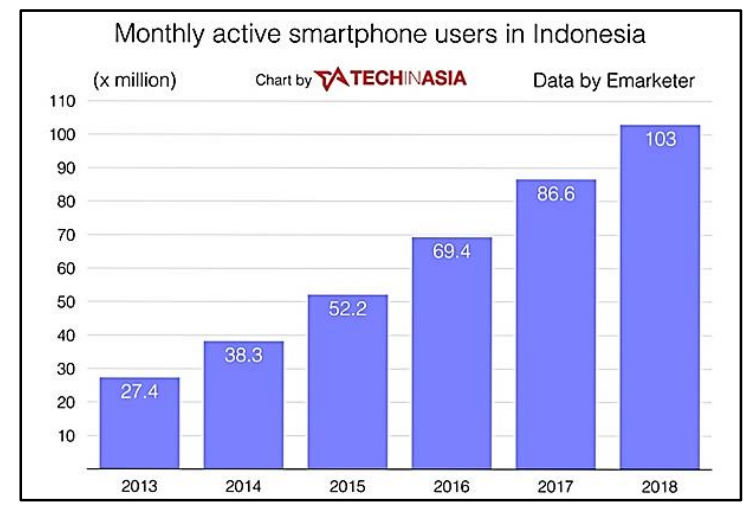

Gambar 2. Peningkatan Pengguna Smartphone di Indonesia [8]

\section{Pembahasan}

Pengembangan aplikasi multimedia pembelajaran konversi bilangan dan warna ini menggunakan metode prototype. Adapun beberapa hal yang dilakukan dalam desain antarmuka aplikasi konversi bilangan dan warna ini, diantaranya :

1. Pendekatan user centered design dipilih untuk mendesain antarmuka aplikasi. Pendekatan ini dipilih karena peneliti akan melibatkan pengguna dalam menentukan bentuk desain antarmuka yang terbaik bagi pengguna. Dalam hal ini peneliti berdiskusi dengan sampel pengguna (dosen dan mahasiswa).

2. Peneliti juga memperhatikan kebiasaan para sampel pengguna tersebut dalam menggunakan beberapa aplikasi sejenis.

3. Peneliti menentukan komposisi warna, tipografi, konten, layout, navigasi, dan elemen aplikasi untuk menjadi pertimbangan guna mendapatkan desain antarmuka yang baik bagi pengguna.

Adapun antarmuka yang akan didesain, diantaranya :

1. Logo dan nama aplikasi 
2. Navigasi antarmuka

3. Halaman awal (splash page)

4. Halaman menu

5. Halaman pendahuluan

6. Halaman materi yang dipilih

7. Halaman materi

8. Halaman latihan

9. Halaman kalkulator bilangan dan warna

10. Halaman kuis

Desain antarmuka aplikasi multimedia pembelajaran konversi bilangan dan warna ini dimulai dengan melakukan desain logo aplikasi, kemudian merancang navigasi (mapping) antarmuka, dan dilanjutkan dengan desain antarmuka.

\section{A. User Centered Design}

User centered design (UCD) merupakan sekumpulan dari beberapa teknik faktor manusia yang disatukan dibawah filosofi memahami pengguna dan melibatkan mereka dalam aktivitas desain (Norman, 1986., Constantine, 2002). Pendekatan ini berfokus pada enduser aplikasi. Pembahasan desainnya berorientasi pada pengalaman pengguna (user experience) dan kenyamanan pengguna (user satisfaction) dari desain aplikasi yang akan dihasilkan. Oleh karena itu, diperlukan studi pengguna untuk mengidentifikasi kebutuhan pengguna, rapid paper prototyping untuk mendapatkan umpan balik dari pengguna tentang rutinitas penggunaan desain antarmuka nantinya, dan pengujian usabilitas prototipe desain.

Pendekatan UCD didukung dengan teknik, tools, prosedur, dan proses yang membantu perancangan sistem interaktif yang lebih berpusat pada pengguna (Paskalis, 2015). Sasaran UCD adalah lebih dari sekedar membuat produk yang berguna. Prinsip yang harus diperhatikan dalam tinjauan aspek peran UCD dalam kualitas informasi mengetahui kebutuhan dari pengguna sistem informasi :

1. Fokus pada pengguna. Pada saat perancangan akan berhubungan langsung dengan calon pengguna atau pengguna melalui interview, survey, dan partisipasi dalam workshop perancangan. Tujuannya untuk memahami kognisi, karakter, dan sikap pengguna. Aktivitas utamanya mencakup pengambilan data, analisis dan integrasinya ke dalam informasi perancangan dari pengguna tentang karakteristik tugas, lingkungan teknis, dan organisasi.

2. Perancangan terintergrasi. Perancangan harus mencakup antarmuka pengguna, sistem bantuan, dukungan teknis serta prosedur instalasi dan konfigurasi.

3. Pengujian pengguna. Satu-satunya pendekatan yang sukses dalam perancangan sistem yang berpusat pada pengguna adalah secara empiris dibutuhkan observasi tentang kelakuan pengguna dan evaluasi umpan-balik yang cermat.

4. Perancangan interaktif. Sistem yang sedang dikembangkan harus didefinisikan, dirancang, dan diuji berulang kali. Berdasarkan hasil test kelakuan dari fungsi, antarmuka, sistem bantuan, dokumementasi pengguna, dan pendekatan pelatihannya.

Proses pada User Centered Design (UCD) merupakan proses yang berulang (iterative) dimana tahap desain dan evaluasi dibangun dari tahap awal proyek hingga tahap implementasi.

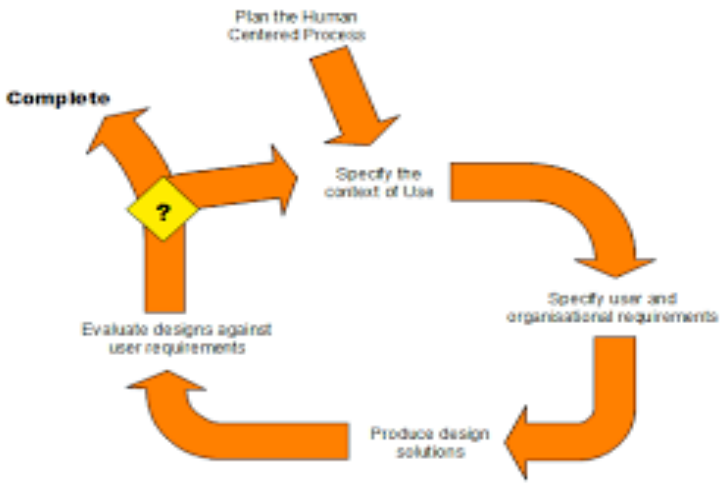

Gambar 3. Proses UCD berdasarkan ISO 13407:1999

Diperlukan ketelitian saat melibatkan pengguna dalam proses desain, mengenai siapa saja dan bagaimana pengguna terlibat (Akhsan, 2017). Tahapan ketiga saat pembangunan sistem UCD adalah menghasilkan solusi perancangan. Pada saat menghasilkan solusi perancangan, dilakukan sebanyak tiga kali iterasi pembangunan antarmuka sistem hingga diperoleh solusi perancangan yang benar-benar sesuai dengan kebutuhan pengguna (Saputri, 2017). Sejalan dengan definisinya, pendekatan ini dipilih karena peneliti akan melibatkan pengguna dalam menentukan bentuk desain antarmuka yang terbaik bagi pengguna. Dalam hal ini peneliti berdiskusi dengan sampel pengguna (dosen dan mahasiswa).

\section{B. Desain Logo}

Logo dari aplikasi multimedia pembelajaran konversi bilangan dan warna dibuat dengan bentuk persegi. Ada 4 bentuk persegi yang masing-masing melambangkan operator hitung, diantaranya tanda plus $(+)$, tanda minus $(-)$, tanda kali (x), dan tanda bagi $(\div)$. Disebelah logo aplikasi diberikan teks yang melambangkan nama dari aplikasi. Nama yang diberikan untuk aplikasi ini adalah "Chronum Calculator". Nama ini merupakan akronim dari kata "Chromosome and Numbering (ChroNum)" dan kata "Calculator" karena aplikasi ini digunakan untuk menghitung atau mengkonversi. Nama Chromosome dipilih karena dalam pemrograman, materi konversi bilangan masuk dalam teori chromosome algoritma genetika, dimana chromosome ini dapat dibentuk dari bilangan numerik (integer/real), biner, maupun karakter (Handayani, 2016). Gambar 3 menunjukkan desain logo yang telah dirancang. 


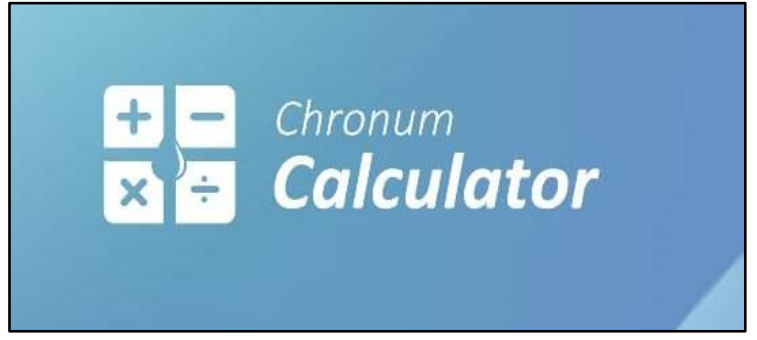

Gambar 4. Desain Logo Aplikasi

\section{Desain Navigasi}

Aplikasi multimedia pembelajaran konversi bilangan dan warna ini dirancang dengan lima buah menu, yang terdiri dari pendahuluan, materi belajar, kalkulator, kuis, dan latihan. Kelima menu ini dapat diakses secara acak. Akan tetapi akan lebih baik jika pengguna yang baru pertama kali mengaksesnya membuka halaman pendahuluan terlebih dahulu baru mengakses halaman lainnya. Terakhir sekali baru mengakses halaman kuis untuk mengukur pemahaman materi dan keberhasilan belajar. Gambar 4 menunjukkan rancangan struktur navigasi pada aplikasi ini.

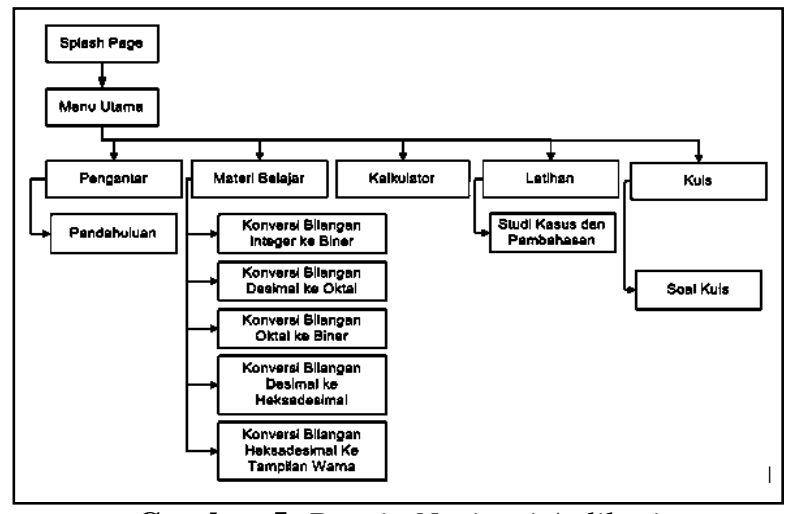

Gambar 5. Desain Navigasi Aplikasi

\section{Desain Antarmuka}

Desain prototipe antarmuka multimedia pembelajaran konversi bilangan dan warna dibuat sesuai desain navigasi seperti pada gambar 5. Teknik desainnya menggunakan pendekatan user centered desain (UCD). Pada pendekatan ini melibatkan sampel calon pengguna aplikasi yaitu dosen dan mahasiswa. Para sampel calon pengguna diajak berdiskusi tentang kebutuhan dan spesifikasi antarmuka media pembelajaran multimedia yang membahas materi konversi bilangan dan warna. Tentunya dalam diskusi ini peneliti akan menjelaskan kelebihan dan kekurangan dari rancangan antarmuka, serta kesulitan yang mungkin akan dihadapi pada saat implementasi desain antarmuka yang diiginkan oleh sampel calon pengguna aplikasi. Dengan cara seperti ini, pengguna seolah-olah sudah mempunyai gambaran nyata tentang antarmuka yang nanti akan mereka gunakan (Oktaviani, 2014).

Desain antarmuka dimulai dari halaman awal (splash page) seperti pada gambar 6. Halaman ini merupakan cover dari beberapa halaman lainnya. Di halaman ini berisi logo, nama, judul, dan tombol mulai untuk mengakses halaman lain pada aplikasi. Setelah klik

tombol mulai dihalaman awal, maka akan ditampilkan halaman menu (gambar 7) yang terdiri dari pendahuluan (gambar 8), materi (gambar 9a dan 9b), kalkulator bilangan dan warna (gambar 10 dan gambar 11), latihan (gambar 12) dan kuis (gambar 13).

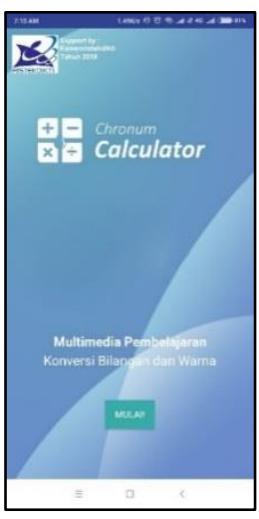

Gambar 6. Halaman Awal (Splash Page)

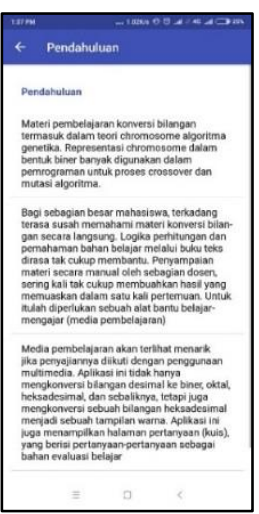

Gambar 8. Halaman Pendahuluan

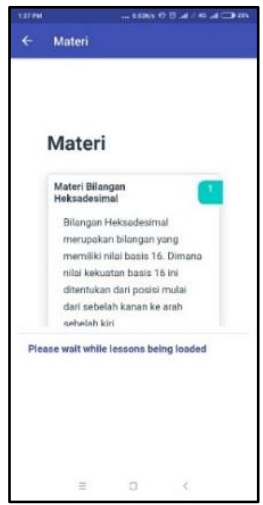

Gambar 9b. Halaman Materi Yang Dipilih

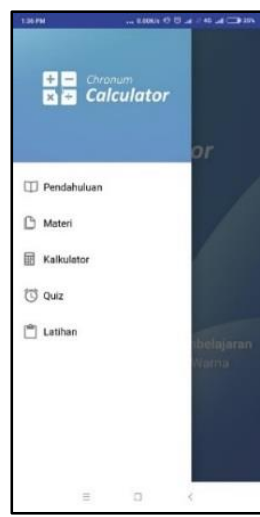

Gambar 7. Halaman Мепи

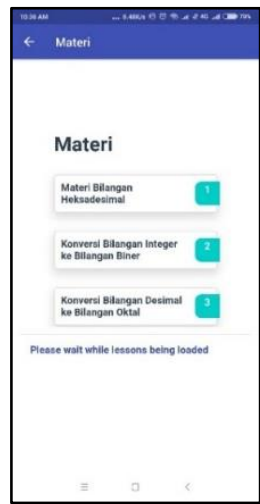

Gambar 9a. Halaman Materi

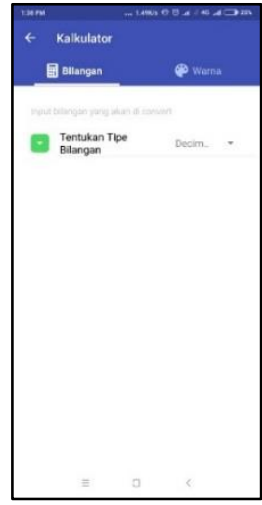

Gambar 10. Halaman Kalkulator Bilangan 


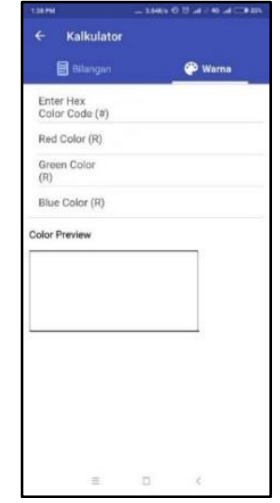

Gambar 11. Halaman Kalkulator Warna

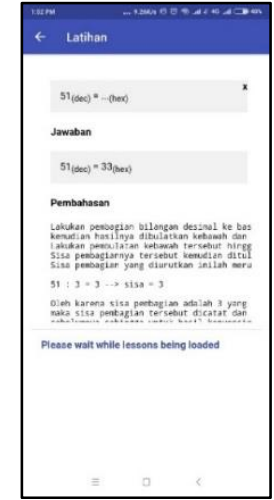

Gambar 12. Halaman Latihan

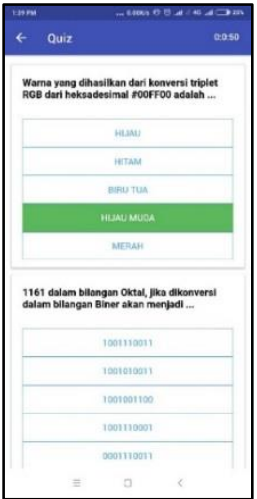

Gambar 13. Halaman Kuis

\section{E. Pengujian Desain Antarmuka}

Pada gambar 5 diposisi kiri atas, ditampilkan halaman awal yang berisi logo kemenristekdikti sebagai lembaga pendukung finansial penelitian pada program hibah penelitian dosen pemula 2019. Selain itu, ditampilkan juga nama dan logo aplikasi serta tombol untuk mulai menggunakan aplikasi. Diposisi tengah bawah, ditampilkan teks berupa keterangan singkat mengenai aplikasi.

Gambar 6 ditampilkan halaman menu, dimana pada halaman ini masih ditampilkan nama dan logo aplikasi beserta daftar menu tampilan aplikasi. Dari halaman menu (gambar 6) pengguna bisa memilih akan menampilkan halaman lainnya yang terdiri dari pendahuluan (gambar 7) yang berisi pengantar maksud dan tujuan penggunaan aplikasi ini. Selain itu ada juga pilihan halaman materi (gambar 8a dan 8b), halaman kalkulator konversi bilangan (gambar 9) dan halaman kalkulator konversi warna (gambar10). Ada juga halaman latihan soal konversi bilangan dan warna (gambar 11). Pada halaman latihan soal ini, sebaiknya pengguna telah mengakses dan membaca semua materi belajar yang ada pada halaman materi (gambar 8a dan 8b) kemudian mengerjakan semua soal latihan konversi bilangan yang ada di halaman latihan ini. Selain itu ada juga halaman kuis (gambar 12). Pada halaman ini pengguna diberikan waktu \pm 30 menit untuk 10 soal kuis. Setelah waktu habis dan pengguna selesai mengerjakan soal kuis ini, akan ditampilkan nilai dan jawaban yang benar atau salah dari semua soal kuis yang disediakan.

\section{Kesimpulan}

Antarmuka (interface) merupakan komponen yang penting dalam penyampaian informasi. Desain antarmuka yang baik akan membantu proses penyampaian informasi dengan lebih mudah. Dalam penelitian kali ini telah dihasilkan desain antarmuka untuk multimedia pembelajaran konversi bilangan dan warna. Dimana terdapat beberapa halaman mulai dari halaman awal (splash page), halaman menu, halaman pendahuluan, halaman materi belajar, halaman kalkulator bilangan, halaman kalkulator warna, halaman latihan dan halaman kuis. Untuk memasuki tahapan pengembangan selanjutnya, rancangan tampilan antarmuka multimedia pembelajaran konversi bilangan dan warna kiranya dapat direalisasikan dalam kegiatan pengkodean aplikasi. Untuk kemudian dirilis dalam play store agar dapat diunduh oleh mahasiswa atau dosen sebagai penggunanya.

\section{Daftar Pustaka}

Akhsan, A.A. dan Faizah. 2017. Analisis Dan Perancangan Interaksi Chatbot Reminder Dengan User-centered Design. Jurnal Sistem Informasi (Journal of Information System), Volume 13, Issue 2, October $2017 . \quad$ DOI: http://dx.doi.org/10.21609/jsi.v13i2.555.

Constantine, L. and Lucy Lockwood. Usage-Centered Engineering for Web Application. IEEE Software 19(2): $\quad 42-50, \quad$ April 2002. https://www.researchgate.net/publication/3247829 Usage-centered_engineering_for_Web_applications Daryanto. 2010. Media Pembelajaran. Bandung: Satu Nusa, halaman 49.

Fauzia, S., Agustin, F.I.M., Syaripudin, U., dan Ichsani, Y. 2016. Perancangan Prototype Tampilan Antarmuka Pengguna Aplikasi Web Kamardagang.com Dengan Teknik Flat Design Pada PT Selaras Utama Internasional. Jurnal Teknik Informatika Vol.9 No.2, Oktober 2016, halaman 148-157.

Handayani, F.S.. 2016. Konsep dan Desain Multimedia Pembelajaran Kalkulator Konversi Bilangan dan Warna Prosiding CITISEE 2016 ISBN: 978-60260280-1-3

Kartikasari, G.. 2016. Pengaruh Media Pembelajaran Berbasis Multimedia Terhadap Motivasi dan Hasil Belajar Materi Sistem Pencernaan Manusia : Studi Eksperimen Pada Siswa Kelas V MI Miftahul Huda Pandantoyo. Jurnal Dinamika Penelitian Vol.16, No.1, Juli 2016. Diakses pada halaman http://ejournal.iaintulungagung.ac.id/index.php/dinamika/article/view/ 139

Millward, S. Indonesia to be world's fourth-largest smartphone market by 2018. 
https://www.techinasia.com/. Web. 23 Dec 2014. Diakses pada tanggal 12 Januari 2019.

Norman, D. A., and Draper, S. W. 1986. User Centered Design. Hillsdale, NJ: Lawrence Erlbaum.

Oktaviani, T., Widyawan, dan Bimo Sunarfi Hantono. 2014. Perancangan User Interface Berbasis Web Untuk Home Automation Gateway Yang Berbasis IQRF TR53B. Seminar Nasional Teknologi Informasi dan Komunikasi (SENTIKA), Yogyakarta, 15 Maret 2014, ISSN:2089-9813

Paskalis, P., H. Hidayati, E. Darwiyanto. 2015. Implementasi User Centered Design untuk Merancang Antarmuka Sistem Informasi Eksekutif pada PT Pos Indonesia. e-Proceeding of Applied Science : Vol.1, No.1 April 2015. ISSN : 24425826

Rauschenberger, M., dkk.2013. Efficient Measurement of the User Experience of Interactive Products. International Journal of Artificial Intelligence and Interactive Multimedia, Vol. 2, No 1.

Roth, R. E. 2017. User interface and User Experience (UI/UX) Design. The Geographi Information Science \& Technology Body of Knowledge (2nd Quarter 2017 Edition), John P. Wilson (ed.).

Saputri, I.S.Y., , M. Fadhli , I. Surya. 2017. Penerapan Metode UCD (User Centered Design) pada ECommerce Putri Intan Shop Berbasis Web. Jurnal Teknologi dan Sistem Informasi. ISSN (Online) 2476-8812. https://doi.org/10.25077/ TEKNOSI.v3i2.2017.269-278.

Tanzil, F., Aulia, A., Machyar, M.R.R., Sembiring, E.F., dan Ridwan, M. 2018. Pengembangan Aplikasi Game Mobile "Batik Yuk" Berbasis Android. Jurnal Teknik dan Ilmu Komputer Vo.7 No.28, Oktober-Desember 2018.

Wibawanto, W. 2017. Desain dan Pemrograman Multimedia Pembelajaran Interaktif. Jember: Cerdas Ulet Kreatif Publisher. 